\title{
PENINGKATAN KETANGGUHAN DAN KELEKATAN ORANGTUA ANAK BERKEBUTUHAN KHUSUS DALAM MENGATASI STRES PENGASUHAN DI MASA PANDEMIK COVID-19
}

\author{
Naomi Soetikno ${ }^{1}$, Pamela Hendra Heng ${ }^{1}$, Nevy Prinanda Putri ${ }^{1}$ dan Inke Ayu Pertiwi ${ }^{1}$ \\ ${ }^{1}$ Jurusan Psikologi, Universitas Tarumanagara Jakarta \\ Email: naomis@fpsi.untar.ac.id
}

\begin{abstract}
Children are a gift from God that is coveted by every married couple. The child will be the hope of the next generation that is better than the child's parents. Parents always expect their children to develop well and perfect physically, socially, mentally and cognitively. However, in reality this desire is sometimes not in line with expectations, especially parents who get their children as children with special needs. In the COVID-19 pandemic situation, handling children with special needs can be a challenge for parents. Many parents are unable to cover up their feelings of stress, anxiety, fear, hopelessness, inadequacy, and panic in a pandemic situation. Moreover, parents who work from home during the pandemic must also divide their time to teach children with special needs to learn from home (study from home) so that the challenges they face are increasing as well. Therefore, to cope with parenting stress, parents need to increase resilience and attachment. The provision of psychoeducation in an effort to increase parental resilience and attachment is an approach used and given to parents in special needs schools, Hidayah Edukasi foundation, preschool Sahabat Montessori, South Jakarta, during the Covid-19 pandemic. By giving pre-test and post-test to measure the understanding of participant (parents and teachers) regarding the parenting stress, attachment, and resilience, the difference was obtained ranging from 0.02-0.54, which indicated that there was an increase in understanding of the participants.
\end{abstract}

Keywords: Parenting stress, Resilience, Attachment, Special needs children

\begin{abstract}
ABSTRAK
Anak adalah anugerah dari Tuhan yang didambakan oleh setiap pasangan suami istri. Anak akan menjadi harapan penerus generasi yang lebih baik dari orangtua sang anak. Orangtua selalu mengharapkan anak mereka dapat berkembang dengan baik dan sempurna secara fisik, sosial, mental dan juga kognitif. Namun pada kenyataannya keinginan tersebut terkadang tidak sesuai dengan harapan, khususnya orangtua yang mendapatkan anaknya sebagai anak berkebutuhan khusus. Dalam situasi pandemic COVID-19, penanganan anak-anak berkebutuhan khusus dapat menjadi tantangan bagi orangtua. Banyak orangtua yang tidak dapat menutupi rasa stres, cemas, takut, putus asa, tidak mampu, dan panik dalam situasi pandemik. Terlebih lagi orangtua yang bekerja dari rumah (work from home) selama pandemik juga harus membagi waktu untuk mengajari anak berkebutuhan khusus belajar dari rumah sehingga tantangan yang dihadapi semakin meningkat pula. Untuk mengatasi stress pengasuhan, orangtua perlu meningkatkan ketangguhan dan kelekatan. Pemberian psikoedukasi dalam upaya peningkatan ketangguhan dan kelekatan orangtua merupakan pendekatan yang digunakan dan diberikan kepada para orangtua di sekolah kebutuhan khusus Yayasan Hidayah Edukasi KB-TK Sahabat Montessori, Jakarta Selatan, di masa pandemic Covid-19. Dengan pemberian pretest dan post-test untuk mengukur pemahaman peserta yakni orangtua dan guru, mengenai stress pengasuhan, kelekatan orangtua, serta ketangguhan orangtua, didapatkan selisih berkisar 0.02-0.54, yang menunjukkan bahwa adanya peningkatan pemahaman dari peserta.
\end{abstract}

Kata Kunci: Stress pengasuhan, Ketangguhan, Kelekatan orangtua, Anak berkebutuhan khusus

\section{PENDAHULUAN}

Corona Virus (COVID-19) telah menjadi pandemik sehingga pemerintah mengeluarkan keputusan yang menyatakan pembatasan untuk mencegah penyebarannya secara meluas (Nelson, 2020). Pada saat ini, belum ada vaksin atau obat yang mampu menyembuhkan penyakit ini (Chen et al., 2020) namun, berita dari negara-negara menunjukkan bahwa jumlah kasus dan angka kematian meningkat dari hari ke hari. Sebagai hasil dari penyebaran wabah dan meningkatnya angka kematian, pada tanggal 30 Januari 2020, Organisasi Kesehatan Dunia (WHO) mendeklarasikan darurat kesehatan masyarakat global (WHO, 2020). Dalam berjuang melawan wabah, tindakan cepat dan protektif diambil oleh pemerintah Cina pertama kali dan kemudian diikuti oleh pemerintah negara lain di seluruh dunia. 
Sejumlah langkah diambil oleh pemerintah, seperti mengkarantina kota, mengumumkan jam malam, menutup area publik, peringatan larangan bepergian, izin publik untuk orang-orang dengan kondisi kronis atau usia lanjut dan penutupan sekolah. Langkah-langkah yang diambil untuk membatasi paparan publik terhadap virus mengharuskan seluruh lapisan masyarakat di seluruh dunia untuk tinggal di rumah, termasuk anak-anak berkebutuhan khusus.

Anak berkebutuhan khusus (ABK) adalah anak yang proses pertumbuhan atau perkembangannya mengalami kelainan dalam segi fisik, mental-intelektual, sosial, dan emosional, sehingga memerlukan pelayanan pendidikan khusus. Kelainan yang dimaksud dalam definisi tersebut yaitu tunanetra, tunarungu, tunagrahita, tunadaksa, tunalaras, lamban belajar, berbakat, gangguan komunikasi, ADHD, dan autism (Syafarana \& Chairani, 2020). Berbagai kebutuhan khusus dari anak-anak ini membuat banyaknya keterbatasan yang mampu dilakukan anak yang berbeda dengan anak pada umumnya secara normal. Keterbatasan yang dimiliki berkaitan dengan kondisi kecacatan fisik yang dialami, keterbatasan dalam hal pengelolaan kognisi, emosi, serta perilaku dan sosialnya. Keterbatasan yang dimiliki oleh anak dengan berkebutuhan khusus membuat mereka membutuhkan tempat belajar yang khusus disesuaikan dengan keadaan mereka.

Terdapat beberapa pendidikan anak berkebutuhan khusus yaitu: a) segresi, salah satu bentuk sekolah untuk anak-anak berkebutuhan khusus yang terpisah dari system pendidikan umum; b) integrasi, suatu sistem pendidikan yang memberikan kesempatan peserta didik berkebutuhan khusus untuk mengikuti pendidikan di sekolah umum bersama-sama dengan anak-anak pada umumnya tanpa diberikan perlakuan khusus; dan c) inklusi, pendidikan yang menempatkan anak berkebutuhan khusus di sekolah umum dengan belajar bersama dengan anak normal dan memberikan perlakuan yang sesuai bagi anak berkebutuhan khusus (Stubbs, 2002). Namun, karena adanya tindakan pencegahan wabah, anak-anak berkebutuhan khusus secara fisik tidak didukung oleh terapis dan tidak dapat menghadiri intervensi tersebut. Langkah-langkah tersebut diambil untuk kesehatan masyarakat, sehingga perlu ditangani dengan hati-hati untuk menghindari peningkatan stres orang tua dan memperburuk masalah perilaku anak-anak berkebutuhan khusus (Narzisi, 2020).

Dalam situasi ini, penanganan anak-anak dengan berkebutuhan khusus dapat menjadi tantangan bagi orangtua. Keterbatasan dan tingkah laku anak berkebutuhan khusus jelas tidak sama dengan anak-anak lain, membuat orangtua menjadi bekerja lebih keras lagi untuk mengasuh anak agar dapat bertahan hidup. Sehingga orangtua diharuskan melakukan pendampingan khusus kepada anak, membantu setiap aktivitas yang anak kerjakan. Hal ini tentu saja menambah tugas bagi orangtua dan menjadikan orangtua lebih tertekan (Kiani et al., 2014). Banyak orangtua yang tidak dapat menutupi rasa stres, cemas, takut, putus asa, tidak mampu, dan panik dalam situasi pandemik. Terlebih lagi orangtua yang bekerja dari rumah (work from home) selama pandemik juga harus membagi waktu untuk mengajari anak berkebutuhan khusus belajar dari rumah (study from home) sehingga tantangan yang dihadapi semakin meningkat pula.

Orangtua sebagai pengasuh utama untuk anaknya terlebih anak dengan berkebutuhan khusus dapat mengalami stress dikarenakan kondisi pandemic. Stress yang dialami oleh orangtua dapat berdampak pada stress pengasuhan yang diberikannya kepada anak. Orangtua yang mengasuh anak berkebutuhan khusus dan merasakan adanya stress atau tertekan dengan keadaan juga dapat memengaruhi sikapnya terhadap anak dalam arti kelekatan yang diberikan. Kelekatan sebagai salah satu unsur dalam pengasuhan sangat dibutuhkan agar anak dapat merasakan keamanan dalam pertukbuhan dan perkembangannya. Memahami situasi pendemik COVID-19 yang tidak juga kunjung selesai, para orangtua yang mengasuh anaknya yang berkebutuhan khusus juga 
memerlukan sumber daya baik internal maupun eksternal dalam menghadai kondisi tertekan. Ketangguhan atau sering disebut sebagai resiliensi diperlukan oleh para orangtua dalam mengahdapi situasi saat ini dan kondisi kebutuhan khusus dari anaknya.

Mitra dalam kegiatan pengabdian kepada masyarakat ini adalah sekolah di bawah Yayasan Hidayah Edukasi Sahabat Montessore tingkat kelompok bermain (KB) dan taman kanak-kanak (TK) di wilayah Jakarta Selatan. Sekolah ini menerima siswa-siswi pada taraf usia di tiga sampai enam tahun, dan beberapa diantaranya memiliki kebutuhan khusus. Di masa pandemic Covid-19 kegiatan belajar mengajar di sekolah ini digantikan dengan kegiatan pembelajaran jarak jauh dan salah satu metode yang diterapkan adalah memberikan arahan kepada orangtua mengenai kegiatan-kegiatan belajar yang perlu dilakukan di rumah. Pemantauan dari pihak sekolah kepada kegiatan siswa dilakukan melalui komunikasi di handphone maupun dilakukannya kunjungan rumah. Diketahui dari hasil kunjungan pihak sekolah kepada para orangtua siswanya bahwa adanya keluhan mengenai stress orangtua dalam pengasuhan kepada anaknya selama kegiatan pembelajaran jarak jauh di masa pandemic Covid-19 ini.

\section{METODE PELAKSANAAN PKM}

\subsection{Tahapan Pelaksanaan}

Metode pelaksanaan dengan penyuluhan yang berupa psikoedukasi pada orangtua, guru dan pengasuh anak berkebutuhan khusus agar tercapainya maksud dan tujuan dari pengabdian kepada masyarakat ini. Pelaksanaan diawali dengan menghubungi mitra yaitu Kepala Yayasan Hidayah Edukasi KB - TK Sahabat Montessori untuk mengurus perizinan, mengurus persiapan kegiatan, pelaksanaan kegiatan sesuai dengan waktu yang telah ditentukan. Sebelum penyuluhan dilakukan, para peserta diberikan kuesioner pre-test untuk mengetahui pengetahuan mengenai stres pengasuhan di masa pandemik COVID-19 serta penanganannya. Setelah penyuluhan peserta akan diberikan kuesioner post-test untuk mengetahui pengetahuan mengenai stres pengasuhan di masa pandemik COVID-19 serta penanganannya. Akhir dari kegiatan ini ialah menghitung hasil selisih dari pre-test dan post-test untuk menilai efektifitas dari penyuluhan yang diberikan. Selanjutnya, dibuat laporan kegiatan yang dapat dipublikasikan pada jurnal ilmiah.

\section{Waktu dan Lokasi Pelaksanaan PKM}

Kegiatan psikoedukasi dilakukan pada hari Sabtu, tanggal 24 April 2021 pada pukul 14.00-16.30 WIB. Kegiatan ini diselenggarakan melalui media konferensi daring yakni aplikasi Zoom.

\section{Bentuk Kegiatan}

Kegiatan Pengabdian Kepada Masyarakat dalam bentuk Penyuluhan Psikoedukasi atau Seminar yang dilakukan secara daring dengan susunan susunan acara yang dimulai dari kegiatan pendaftaran peserta untuk memasuki ruang media konferensi daring. Kemudian setelah jumlah peserta sesuai dengan daftar peserta yang diajukan oleh pihak sekolah, acara dibuka oleh pembawa acara dari pihak pelaksana pengabdian kepada masyarakat ini. Setelah pembawa acara membuka acara, kemudian peserta diminta untuk mengisi pre-test yang diberikan melalui kolom chat. Acara dilanjutkan dengan beberapa sambutan yakni dari ketua tim kegiatan dan sambutan dari kepada sekolah KB Sahabat Montessori. Selanjutnya pemaparan materi psikoedukasi terkait topik stress pengasuhan, kelekatan orangtua anak berkebutuhan khusus, serta materi psikoedukasi ketangguhan orangtua anak berkebutuhan khusus. Sebelum penutupan, dilakukan kegiatan tanya jawab dan peserta kembali mengisi formulir post-test yang dibuat dalam bentuk elektronik ( $g$ form). 


\subsection{Partisipasi Mitra dalam Kegiatan PKM}

Mitra menyediakan fasilitas berupa peserta kegiatan seminar daring sejumlah 26 orang yang merupakan orangtua, guru, wali, dan pemerhati anak berkebutuhan khusus dari sekolah KB - TK Sahabat Montessori dan memberikan e-sertifikat kepada para pembicara.

\section{HASIL DAN PEMBAHASAN}

Analisa hasil atas pemberian penyuluhan berupa psikoedukasi ini didapatkan dari selisih antara nilai pre-test dengan nilai post-test yang diberikan kepada peserta. Terdapat 3 buah pertanyaan mengenai pengetahuan peserta mengenai Stres pengasuhan, 2 pertanyaan mengenai pengetahuan akan Kelekatan orangtua-anak berkebutuhan khusus, dan 2 pertanyaan mengenai pengetahuan akan Ketangguhan orangtua dalam mengasuh anak berkebutuhan khusus. Pertanyaan disusun untuk mendapatkan jawaban partisipan dengan skala Likert yakni nilai 1 bila Sangat Tidak Setuju, 2 bila Tidak Setuju, 3 bila Ragu-Ragu, nilai 4 bila Setuju, dan nilai 5 bila Sangat Setuju.

Dari hasil jawaban peserta seminar daring dilakukan penghitungan rerata dari setiap variable yang dijelaskan baik dari hasil pre-test maupun hasil post-test. Berikut ini akan dijelaskan mengenai perbandingan nilai pre-test dan post-test setiap variabelnya seperti pada Tabel 1.

Tabel 1

Hasil Perbandingan Rerata Nilai Pre-Test dan Post-Test Psikoedukasi

\begin{tabular}{ccc}
\hline Variabel & Pre-test & Post-test \\
\hline Stres Pengasuhan & 4.15 & 4.56 \\
$\quad$ Kelekatan & 4.13 & 4.15 \\
Orangtua-ABK & & \\
Ketangguhan & 4.13 & 4.67 \\
Orangtua ABK & & \\
\hline
\end{tabular}

Dari hasil perbandingan atas nilai pre-test dengan post-test untuk variable Stres Pengasuhan diketahui terdapat selisih 0.41 poin. Dengan adanya selisih ini menunjukan bahwa terdapat perubahan yakni adanya peningkatan pemahaman dari peserta mengenai Stres Pengasuhan kepada anak berkebutuhan khusus di masa pandemik COVID-19 ini. Stres pengasuhan dalam penyuluhan disampaikan dengan menjelaskan pengertian dari Stres Pengasuhan, bentuk atau reaksi dari stress pengasuhan, faktor yang memengaruhi stres, sampai materi mengenai manajemen stres. Dengan adanya sesi penyuluhan membuat para orangtua khususnya ibu akan mendapatkan pengetahuan mengenai stress dan pengelolaanya sehingga penghayatan pesimis dari orangtua dapat dikurangi.

Stres yang dialami oleh orangtua atau pengasuh berbeda kondisinya antara orangtua yang memiliki anak dengan kecacatan dengan yang tidak, terutama terkait dengan area stress dari kondisi anak itu sendiri, sehingga dapat berkelanjutan dengan meningkatnya risiko adanya gangguan pada kesejahteraan dan kesehatan mental dari orangtua (Felizardo et al., 2016). Stres yang dialami oleh ibu dari anak dengan disabilitas berhubungan dengan perasaan pesimis ibu akan masa depan anak (Little, 2002 dalam Lubis, 2019), orangtua juga harus melakukan banyak tugas, termasuk mengasuh anak, pendidikan, rehabilitasi, dan pelatihan yang dapat meningkatkan stres pengasuhan (Chen et al., 2020).

Menurut Berry dan Jones (Kurniadi et al, 2019) stres pengasuhan terdiri dari 2 dimensi yaitu a) dimensi pleasure dan b) dimensi strain. Dimensi pleasure merupakan komponen positif dari pengasuhan yang membawa keuntungan secara emosional seperti cinta, kegembiraan, kebahagiaan, kesenangan serta perasaan akan pengembangan diri. Untuk dimensi strain, merupakan komponen negatif dari pengasuhan yang melibatkan tuntutan akan berbagai sumber 
seperti waktu, tenaga, dan uang, serta adanya larangan, perasaan malu, dan kontrol. Dari penjelasan dimensi mengenai pengasuhan, para orangtua dan guru sebagai pendamping anak berkebutuhan khusus di sekolah menjadi memahami bahwa stress pengasuhan yang terjadi selama mengasuh anaknya memiliki dimensi yang positif maupun yang negative. Dari hasil diskusi dan tanya jawab pada kegiatan penyuluhan juga didapatkan berbagai keluhan dari para orangtua yang merasakan ketidaknyamanan secara psikologis dengan keadaan yang terjadi. Kebutuhan dari orangtua maupun guru dalam mengasuh dan mendidikan anak berkebutuhan khusus dalam kemampuan mengelola stress yang dialami cukup tinggi.

Stress manajemen merupakan salah satu bentuk pengelolaan diri dalam mengatasi dampakdampak dari stress yang dirasakan. Tingkat stress yang di alami orangtua dan guru dari anak berkebutuhan khusus dapat disebabkan oleh manajemen stres yang kurang tepat serta ketidakmampuan dalam menghadapi tekanan atau masalah sehingga menjadikan stress sebagai faktor yang tidak dapat dihindari, Diketahui bahwa adanya hubungan yang signifikan antara kemampuan manajemen stres dengan tingkat stress (Apriliyanti et al., 2018). Terdapat berbagai bentuk dari manajemen stress seperti mengenali sumber-sumber stress, memahami keterkaitan antara keadaan saat ini di sekitar dengan keadaan diri sendiri, mengatur waktu dengan baik, mengerjakan tugas yang menyenangkan.

Dilihat dari perbandingan nilai pre-test dengan post-test untuk variabel Kelekatan Orangtua-Anak Berkebutuhan Khusus diketahui terdapat selisih 0.02 poin. Dengan adanya selisih ini menunjukkan bahwa terdapat perubahan yakni adanya peningkatan pemahaman dari peserta mengenai Kelekatan Orangtua-Anak Berkebutuhan Khusus. Kelekatan Orangtua-Anak Berkebutuhan Khusus dalam penyuluhan disampaikan dengan menjelaskan pengertian dari Kelekatan, berbagai bentuk kelekatan, serta dampak dari kelekatan orangtua kepada anak berkebutuhan khusus, manfaat dari kelekatan, dan juga cara-cara meningkatkan kelekatan orangtua-anak berkebutuhan khusus.

Kelekatan merupakan ikatan emosional yang menetap dan kuat dengan orang yang signifikan, dalam hal ini adalah orang tua, di mana terdapat kontribusi terhadap kualitas hubungan yang terbentuk dari masing-masing pihak. Kelekatan yang terbentuk selama masa kanak-kanak memiliki pengaruh yang penting bagi kepribadian masa dewasa (Bowlby dalam Feist \& Feist, 2010). Anak dengan kebutuhan khusus, utamanya adalah autisme menghindari kelekatan pada afeksi, yang memicu meningkatnya stres di dalam diri ibunya (Weiss, 2002). Dalam hal ini, ibu menjadi kesulitan dalam melakukan bonding sehingga hubungan antara ibu dan anak menjadi kurang lekat. Selain itu, terjadi keterbatasan dalam hal komunikasi dimana orangtua menjadi sulit mengetahui hal yang terjadi pada anak dan apa yang anak inginkan. Dengan adanya penyuluhan yang diberikan, para orangtua semakin memahami kondisi kebutuhan khusus dari anaknya serta berbagai jenis kelekatan yang dapat memberi pengaruh kepada sikap kemandirian anak.

Untuk variabel Ketangguhan Orangtua Anak Berkebutuhan Khusus diketahui juga terdapat selisih hasil pre-test dengan hasil post-test. Diketahui adanya selisih sebesar 0.54 poin dari post-test dengan pre-test, yang menunjukan adanya peningkatan pemahaman peserta mengenai Ketangguhan Orangtua Anak Berkebutuhan Khusus di masa pandemik COVID-19. Materi Ketangguhan orangtua anak berkebutuhan khusus di masa pandemic COVID-19 dijelaskan kepada peserta penyuluhan mencakup pengertian dari ketangguhan, faktor dari ketangguhan, fungsi, dan cara meningkatakan ketangguhan orangtua.

Ketangguhan merupakan kapasitas manusia untuk menghadapi dan mengatasi kesulitan yang diperkuat karena adanya kesulitan-kesulitan dalam hidup. Ketangguhan atau sering disebut 
sebagai resiliensi yang oleh Bitsika et al. (2013) disebutkan bahwa resiliensi dapat berperan sebagai penghambat terhadap perkembangan dari tingkat kecemasan dan depresi orang tua yang memilki anak berkebutuhan khusus contohnya autism. Grotberg (Furqon, 2013), menjelaskan beberapa faktor yang memengaruhi resiliensi pada seseorang, yaitu a) tempramen, b) inteligensi, c) budaya, d) usia, dan e) jenis kelamin. Dengan penyuluhan yang diberikan, para orangtua semakin memahami faktor-faktor yang memengaruhi ketangguhan yang dimiliki. Orangtua dan guru juga memahami dimensi-dimensi dari resiliensi seperti dijekaskan Reivich dan Shatté (Septiyani, 2018) terdiri dari 7 dimensi, yaitu a) regulasi emosi, b) pengendalian impuls, c) optimisme, d) empati, e) analisis masalah, f) efikasi diri dan g) pencapaian.

Dari hasil diskusi orangtua dan guru mengenai ketangguhan yang mereka alami selama mengasuh dan mendidik anak berkebtuhan khusus di masa pandemic ini, diketahui bahwa ketujuh dimensi dilakukan oleh partisipan. Berbagai bentuk ketangguhan yang telah dilakukan partisipan seperti penerimaan diri terhadap keadaan diri dan anaknya yang berkebutuhan khusus, mencari-cari kegiatan positif bersama anak dan keluarga, tetap berhubungan dengan orang lain, dan mereka melakukan pendekatan spiritual kerohanian dalam menguatkan psikologisnya.

\section{KESIMPULAN DAN SARAN}

Hasil kegiatan ini menunjukan bahwa pengetahuan para partisipan peserta seminar daring mengalami peningkatan. Penggunaan metode pre-test dan post-test dapat menjadi indikator keberhasilan kegiatan penyuluhan diketahui dari angka pengetahuan rata-rata partisipan yang mengalami peningkatan. Secara kualitatif peserta juga memberikan tanggapan akan rasa puas pada seminar yang diberikan dan mengajukan beberapa topik bahasan lain untuk membantu pengasuhan kepada anak berkebutuhan khusus.

Untuk pengembangan penelitian dan pengabdian kepada masyarakat selanjutnya terkait dengan diketahuinya dari hasil diskusi pada kegiatan ini. Diketahui bahwa para peserta mengalami stress dalam mengasuh dan mendidikan anak berkebutuhan khusus, maka perlu dilakukan tindakan penyuluhan psikoedukasi mengenai stress menejemen yang baik baik orangtua dan guru.

\section{Ucapan Terima Kasih (Acknowledgement)}

Pengabdian kepada masyarakat ini telah terselenggara dengan kerjasama yang baik serta dukungan hibah pendanaan dari Lembaga Penelitian dan Pengabdian kepada masyarakat (LPPM) Universitas Tarumangara. Kami mengucapkan terima kasih juga atas partisipasi aktif dari para guru dan orangtua dari Yayasan Hidayah Edukasi KB - TK Sahabat Montessori.

\section{REFERENSI}

Apriliyanti, D., Anugrahni, D., \& Agustina, V. (2017) Hubungan Kemampuan Manajemen Stres Dengan Tingkat Stres Pada Orangtua Anak Tunagrahita Di Slbn 1 Palangkaraya. An-Nadaa, hal. 43-46.

Bitsika, V., Sharpley, C. F., \& Bell, R. (2013). The Buffering Effect of Resilience upon Stress, Anxiety and Depression in Parents of a Child with an Autism Spectrum Disorder. Journal of Developmental and Physical Disabilities, 533-543.

Chen, N., Zhou, M., Dong, X., Qu, J., Gong, F., Han, Y., ... \& Zhang, L. (2020). Epidemiological and clinical characteristics of 99 cases of 2019 novel coronavirus pneumonia in Wuhan, China: a descriptive study. The lancet, 395(10223), 507-513.

Felizardo, S., Ribeiro, E., \& Amante, M.J. (2016). Parental adjustment to disability, stress indicators and the influence of social support. Procedia - Social and Behavioral Sciences, $217,830-837$ 
Furqon, M. A. (2013). Dinamika resiliensi pada janda: Studi kasus pada janda yang ditinggal mati pasangan di usia dewasa tengah di Dusun Plumpung Rejo, Desa Karang Tengah Kandangan Kediri (Doctoral dissertation, Universitas Islam Negeri Maulana Malik Ibrahim).

Kiani, F., Khodabakhsh, M. R., \& Hashjin, H. K. (2014). Comparison of Parenting-Related Stress and Depression Symptoms in Mother of Children with and without Autism Spectrum Diorder (ASD). International Journal od Pediatrics (Supplement 5), 2, 31-37.

Kurniadi, G., Atmodiwirjo, E. T., \& Soetikno, N. (2019). HUBUNGAN ANTARA HARAPAN DAN STRES ORANG TUA YANG MEMILIKI ANAK DENGAN AUTISME. Jurnal Muara Ilmu Sosial, Humaniora, dan Seni, 3(2), 358-366.

Narzisi, A. (2020). Handle the autism spectrum condition during Coronavirus (COVID-19) stay at home period: Ten tips for helping parents and caregivers of young children.

Nelson, C.W (2020). COVID-19: Time for WHO to reconsider its stance towards Taiwan. Nature, $579,193$.

Septiyani, N. (2018). Resiliensi Remaja Broken Home (Studi Kasus Remaja Putri di Desa Luwung RT 03 RW 02 Kecamatan Rakit Kabupaten Banjarnegara) (Doctoral dissertation, IAIN PURWOKERTO).

Stubbs, S. 2002. Pendidikan Inklusif: Ketika Hanya Ada sedikit Sumber (terjemahan oleh Septaviana). Bandung: Universitas Pendidikan Indonesia dan idpnorway.

Syafarana, I.A.N. \& Chairani, A. (2020). "Pelaksanaan Pembelajaran Anak Berkebutuhan khusus pada Masa Pandemi Covid-19 di Sekolah Inklusif SDN 12 Gedong”. Jurnal Ortopedagogia, 6(2), 125-129.

World Health Organization (WHO). (2020). WHO Director-General's opening remarks at the media briefing on COVID-19. Retrieved from:

https://www.who.int/dg/speeches/detail/whodirector-general-s-opening-remarks-at-themedia-briefing-on-covid-19---11-march-202 